\title{
CEPEJ AS THE CONSULTATIVE BODY OF THE COUNCIL OF EUROPE, GRANTED WITH THE RESPONSIBILITY OF DEVELOPING AND IMPLEMENTING COMMON STANDARDS IN THE SPHERE OF THE DELIVERY OF JUSTICE
}

R. A. ogly GURBANOV, leading research fellow of the department of international relations and international law of the Institute of Philosophy and Law of the National Academy of Sciences of Azerbaijan, member of the Bureau of the European Commission for the Efficiency of Justice

115, Huseyn Javid prospekt, Baku, Azerbaijan, AZ1073

E-mail: ramingurbanov@yahoo.com

The article is devoted to the work of the European Commission for the Efficiency of Justice, which is the consultative body of the Council of Europe and plays an important role in improving the justice systems of states - members of this regional organization. Byevaluating the quality of justice of the Council of Europe Member-States using own methods, CEPEJ determines problematic aspects of the functioning of the justice system of individual states and proposes ways to resolve them, thus making a significant contribution to the realization and protection of the human right to a fair trial enshrined in Article 6 of the European Convention on Human Rights.

Keywords: Council of Europe, consultative body, commission, efficiency of justice, European Convention on Human Rights, member-states, quality of justice, dispute resolution, case-law, European Court of Human Rights.

\section{ЕКЭП КАК КОНСУЛЬТАТИВНЫЙ ОРГАН СОВЕТА ЕВРОПЫ, ОТВЕТСТВЕННЫЙ ЗА РАЗРАБОТКУ И РЕАЛИЗАЦИЮ ОБЩЕПРИЗНАННЫХ СТАНДАРТОВ В СФЕРЕ ОТПРАВЛЕНИЯ ПРАВОСУДИЯ}

ГУРБАНОВ Рамин Афад оглы, ведущий научный сотрудник отдела международных связей и международного права Института философии и права Национальной академии наук Азербайджана, член Бюро Европейской комиссии по эфффективности правосудия

AZ1073, Азербайджан, г. Баку, просп. Гусейна Джавида, 115

E-mail: ramingurbanov@yahoo.com

Статья посвящена деятельности Европейской комиссии по эфффективности правосудия (ЕКЭП), которая является консультативным органом Совета Европы и играет важную роль в совершенствовании систем правосудия государств членов этой региональной организации. Проводя оценку качества правосудия государств - членов Совета Европы при помощи разработанных ею же методов, ЕКЭП выявляет проблематичные аспекты функционирования системы правосудия отдельных государств и предлагает способы их разрешения, тем самым внося огромный вклад в реализацию и защиту права человека на справедливое судебное разбирательство, закрепленное статьей 6 Европейской конвенции о защите прав человека и основных свобод.

Ключевые слова: Совет Европы, консультативный орган, комиссия, эффективность правосудия, Европейская конвенция о защите прав человека и основных свобод, государства-члены, качество правосудия, разрешение споров, судебная практика, Европейский суд по правам человека.

DOI: $10.12737 / 17114$

$\mathrm{T}$ he European Commission for the Efficiency of Justice (Commission européenne pour l'efficacité de la justice) (hereinafter - CEPEJ or Commission) is an analytical and advisory institution of the Council of Europe, which activities include providing assistance to Member States of the Council of Europe to improve their justicesystems. The establishment of this institution ${ }^{1}$ was intended to increase the efficiency and improve the quality of justice in the Member States in order to bring their

\footnotetext{
${ }^{1}$ Resolution Res(2002)12 on establishment of the European Commission for the Efficiency of Justice (CEPEJ), adopted by the Committee of Ministers on 18 September 2002 at their 808 meeting.
}

judiciary up to the standards and norms of the Council of Europe. The question is primarily about the activities on compliance of the judiciary of the Member States with the requirements related to the quality of justice established by Art. 5, 6, 13 and 14 of the European Convention on Human Rights (the European Convention), which concern the quality of the resolution of legal disputes within the national systems of justice. In other words, the CEPEJ is one of the specialised institutions (its activity is restricted by the administration of justice in the Member States), which has the features of an analytical and advisory authority, and promotes the implementation of the requirements ensuing from the European Convention 
and the case-law of the European Court of Human Rights (hereinafter: the ECHR), in matters of justice ${ }^{2}$.

In particular, the establishment of this authority of the Council of Europe, according to the words of the first President of the CEPEJ ${ }^{3}$, "was due to excessive workload of the ECHR suits, and reducing the load of the latter, by the idea of the creators of the Commission, should be achieved by improving the efficiency and the quality of the judiciary of the Member States, and the offset of the load on litigation from the supranational to the national level". Having regard to the fact that most of the cases under consideration of the ECHR mainly concern violations of fundamental procedural rights - in particular violations of the guarantees of judicial protection enshrined in Art. 6 of the European Convention - it became urgent to establish a Commission.

The activity of the Commission is at the junction of two main activities of the Council of Europe, which, in accordance with the Statute ${ }^{4}$, deal with the fundamental rights and freedoms, democracy and the rule of law, namely, the rights of citizens, which are protected directly by the national systems of justice, as well as the rule of law, which is implemented by the enforcement bodies, under the supervision of the judicial authorities. Achievement of these objectives is carried out including by improving the efficiency and the quality of the judiciary of the Member States that is realized in the framework of the Council of Europe through analytical, expert and advisory activities of the CEPEJ.

It should be noted that, despite the impression left by the CEPEJ establishment documents, in our opinion, its activities should be characterised rather analytical and advisory than recommendatory. Indeed, if we look at the main activities of the Commission, which consist in compiling evaluation reports on European judiciary, in improving the quality of the judiciary as well as the management of judicial time in European court systems, it becomes obvious that its main activity is the assessment of various aspects of the functioning of judiciary on the basis of statistical data and expression of advices to Member States. Of course, positive or negative opinions of the Commission on a particular aspect of the functioning of a given court system could be perceived as a kind of advices addressed to member States, but the core missions of the Commission remain its analytical and research functions. Thus, the activity of the Commission is less invasive in terms of international law and international policies than the activities of other authorities of the Council of

\footnotetext{
${ }^{2}$ See more in details: the opening Speech of Mr. Guy De Vel (Director General of legal affairs, Council of Europe) at the study session on "Justice serving citizens: how to improve the functioning of the judicial system for the benefit of users", preceding the second plenary meeting of the CEPEJ.

${ }^{3}$ E. Desch, Foreword in European Judiciary 2002, Council of Europe Publishing, p. 5.

${ }^{4}$ Statute of the Council of Europe, ETS No. 1.
}

Europe, which explains the less public awareness despite the knowledge of specialists of international law about the CEPEJ activities. Against this background, the present study proves to be more than relevant.

As one of the many institutions of the Council of Europe $^{5}$, the CEPEJ is a structure which interacts with other authorities of the Council of Europe with the assistance of the Justice and Legal Co-operation Department of the Council of Europe, as well as the European Committee on Legal Co-operation (CDCJ). Among the specialised structures of the Council of Europe, which are directly and closely linked with the CEPEJ in view of their profile specialty, which is also aimed at improving the quality of questions about the national systems of justice, can be mentioned: the Consultative Council of European Judges (CCJE) and the Consultative Council of European Prosecutors (CCPE).

In contrast to the CEPEJ, the last bodies mentioned are distinguished by their membership, as well as the specificity of their competence. Indeed, in contrast to the CEPEJ, their work does not focus on issues of improving the efficiency and the quality of national court systems in general, and their corresponding profile orientation issues are: the status of judges in the case of the Consultative Council of European Judges (CCJE); and the status of prosecutors in the case of the Consultative Council of European Prosecutors (CCPE).

The CEPEJ Statute clearly indicates the auxiliary nature of the institution within the Council of Europe, which seeks to promote the main authorities of the latter. Thus, in particular, it specifies that the CEPEJ "Forms advisory opinions at the request of:

the Parliamentary Assembly of the Council of Europe (hereinafter - PACE),

the European Court of Human Rights (the ECHR), the European Committee on Legal Co-operation (CDCJ),

the European Committee on Crime Problems (CDPC), the Steering Committee for Human Rights (CDDH), the Consultative Council of European Judges (CCJE) and the Secretary General".

Moreover, in accordance with the Statute of the Commission (par. 3 Art. 5), the president of the Parliamentary Assembly of the Council of Europe (PACE) and the president of the European Court of Human Rights (ECHR), as well as chairmen of the relevant committees of the Council of Europe, in particular the European Committee on Legal Co-operation (CDCJ), or their representatives can participate in the work of the CEPEJ without the right to vote ${ }^{6}$.

\footnotetext{
${ }^{5}$ See in more detail the organisation of the Council of Europe, for example: F. Benoît-Rohmer, H. Klebes, Le droit du Conseil de l'Europe: vers un espacejuridiqueeuropéen, Council of Europe Publishing, 2005, p. 267.

${ }^{6}$ In turn, representatives of the European Union, which may also participate in the work of the Commission, are not included
} 
It should be noted that this institution has not received regulatory and administrative competence, similar to those granted to such authorities of the Council of Europe as, for example, the Committee of Ministers or the Parliamentary Assembly. Basically, as a subsidiary authority of the Council of Europe and according to par. 2 of Art. 2 of its Statute, "the CEPEJ shall not be a supervisory or monitoring body". A former senior representative of the Council of Europe, Mr. Roberto Lamponi, in the best way possible paid attention to the nature of this institution: "The CEPEJ is a really interesting institution because it has no regulatory authority, but rather it is limited in its organisation to assist States in the implementation of existing rules"7.

According to article 5 of its Statute, the CEPEJ authority lies in the principle of parity (one expert from each of the States, but each State should also nominate a substitute member). Accordingly, all the (47) members of the Council of Europe are represented, which ensures, in our opinion, the Commission's representativeness and credibility, as opinions of different Member States are taken into account by the representatives of the various States. The CEPEJ shall be composed of experts who are best able to contribute to its aims and functions, and who have in particular an indepth knowledge of the administration, functioning and efficiency of civil, criminal and/or administrative justice.

The principle of parity takes on a particular importance since, in the framework of its work, the Commission aims to formulate guidelines to Member States to improve their judiciary with regard to the key requirements of the European Convention. Moreover, regard being had to the fact that the Commission has to organise meetings with representatives of the judiciary of the Member States; carry out activities intended to promote the authorities in reforming their judiciary and assess the quality of their work: it becomes obvious that the composition of this authority is of primary importance.

It is an interesting fact that representatives of nonMember States are associated to the work of this institution, being granted the status of observers. The question is specifically about the representatives of Israel, Canada, Mexico, the United States of America, the Holy See, Morocco and Japan. The Commission is also working with international non-government organisations and even the authorities of the European Union (the Council of the European Union and the European Commission). It is the co-operation with the authorities of the latter that elicits our greatest interest, as we know that the accession of the

in its composition in legal terms, as they are handed down abroad and applied by the Commission Statute (Art. 6) to the category of observers.

${ }^{7}$ Interview with R. Lamponi, $12^{\text {th }}$ September 2005, quoted by J. Petaux in L'Europe de la démocratie et des droits de l'homme: l'action du Conseil de l'Europe, Council of Europe Publishing, 2009, p. 126.
European Union to the European Convention, announced under the additional Protocol No. 14, will require a close collaboration between the two regional organisations (and especially between their judicial authorities). As a consequence, the European Union will have to take into account the principles of the ECHR case-law, including principles relating to court systems and procedural safeguards based on Art. 5, 6, 13 and 14 of the European Convention. Taking into consideration the fact that the European Commission for the Efficiency of Justice has to analyse the daily implementation of these principles in the judiciary of the Member States, the request of the European Union for advice on these issues from the CEPEJ should be natural and the participation of the EU in the work of this authority is necessary.

The Commission operates on the basis of an internal document ${ }^{8}$, developed on its own initiative that indicates the existence of a certain functional autonomy within the authority. This act specifically clarifies that the rules of Resolution Res76(3) governing the activities of all the committees of the Council of Europe set up by the Committee of Ministers, or with its authorisation, apply to the CEPEJ. By inference, the nature of this Commission proves to be comparable to that which is inherent in the data working authorities of the international organisation.

The CEPEJ elects from amongst its members, by secret ballot and by a majority of the votes cast, a president and a vice-president (Art. 2 of the CEPEJ Procedural Rules), as well as two members of the Bureau, which also indicates the existence of a functional internal autonomy. Moreover, the election for these positions in the Commission is carried out quite liberally, as in derogation from the rules of unanimity widely used in international law; the election of the management of the CEPEJ is based on the simple majority (par. 3 Art. 2 of the Procedural Rules) $)^{9}$. The institutional structure of the CEPEJ - Bureau - is endowed with administrative and executive functions (Art. 3) ${ }^{10}$ :

the co-ordination of the activities of the working groups, appointment of chairmen and experts of the CEPEJ working groups;

the distribution of work between the members of the Commission and the working groups;

it is entitled to nominate candidates for the positions of experts,

as well as to perform any other function required by the Commission.

${ }^{8}$ The Rules of Procedure of the European Commission for the Efficiency of Justice, 19 March 2003, CEPEJ/GENERAL(2003)3.

${ }^{9}$ Curiously enough, a similar rule applies in respect of the requirement for quorum. Namely, there shall be a quorum if a majority of the delegations are present (Art. 5 of Procedural Rules).

${ }^{10}$ The four members of the CEPEJ Bureau are experts elected by the representatives of the 47 Member States. Currently they are: President Georg Stawa (Austria), vice-president Irakli Adeishvili (Georgia), Ivana Borzova (Czech Republic) and Ramin Gurbanov (Azerbaijan). 
The Secretariat is established as a part of the CEPEJ and is provided by the Secretary General of the Council of Europe (par. 3 Art. 7 of the Statute).

The Commission also consists of working groups (Art. 6 of the Procedural Rules), which are responsible for the implementation of concrete actions related to the compilation of official documents of the institution. These working groups are of a profile type:

the Working Group on the evaluation of judicial systems (CEPEJ-GT-EVAL);

the Centre for judicial time management or Study and Analysis of judicial Time Use Research Network (SATURN Centre);

the Working Group on quality of justice (CEPEJ-GTQUAL);

the Working Group on execution (CEPEJ-GT-EXE);

the Working Group on mediation or alternative methods of resolving disputes (CEPEJ-GT-MED).

It should be mentioned that the workload is distributed unevenly among these structures of the CEPEJ, since, in our opinion, the first three of them are of a general profile and are permanent (since their creation), while the others are of a narrow-profile and non permanent. At the same time, there is a contradiction in the fact that each of the working groups is made up of an equal number of members (experts) in the CEPEJ. As a result, in practice, the workload imposed on the Commission is distributed evenly mainly among the first three mentioned working groups.

As an advisory institution of the Council of Europe, the role of the CEPEJ in developing and consolidating the Council of Europe law is limited to setting up guidelines, and even (as noted above) carrying out analytical work. However, the impact of its activities extends to both the authorities of the Council of Europe and these of the Member States. Thus, in accordance with the founding act of the CEPEJ ${ }^{11}$, its competence consists in the following functions:

the analysis of the judiciary systems in their compliance with the requirements and standards of the Council of Europe;

the study of problems related to the judiciary and proposals for the resolution of the former and the improvement of the latter;

the organisation of exchange of information on the judiciary;

the provision of legal aid to Member States;

giving assistance to other specialised committees of the Council of Europe in the framework of their standardsetting activities in preparation for the official instruments of the Council of Europe in the area of justice (in particular the European Committee on Legal Co-operation).

Over time, the analytical and advisory functions of the CEPEJ relating to the administration of justice have

${ }^{11}$ Resolution Res(2002)12 on establishment of the European Commission for the Efficiency of Justice (CEPEJ), adopted by the Committee of Ministers on 18 September 2002 at their 808 meeting. evolved. Thus, with the adoption of the Action Plan at the Third Summit of Heads of State and Government, which was hold in Warsaw on 16-17 May 2005, the wish to expand the functions of the Commission has been expressed. Indeed, the Action Plan reflected the commitment of Heads of State "...to develop the function of analysis (evaluation) and the assistance of the European Commission for the Efficiency of Justice, as well as the proper use of the views of the Consultative Council of European Judges to assist Member States in ensuring a fair and timely administration of justice, and also for the development of alternative methods of resolving disputes..."12. Nevertheless, as a result of the adoption of this act, the main functions of the CEPEJ did not change in the frame of the legal regulation of its activity. Changes appeared only on the inter-organisational level, and were expressed in particular in the development of the legal regulation of the CEPEJ analytical work, which had led to the strengthening of the evaluation function of the judiciary ${ }^{13}$.

Providing assistance to Member States of the Council of Europe in improving their systems of justice is, without exaggeration, one of the main functions of the CEPEJ ${ }^{14}$. This assertion stems directly from the Procedural Rules of the Commission. For example, the latter specify that the activities of the Commission in respect of a Member State may be initiated by the concerned Member State, and that such activities are based on mutual legal aid (Art. 8). Groups, consisting of the CEPEJ members (experts), which activity will include one or another mission on providing legal aid to an individual State, will be drawn up on the initiative of the CEPEJ Bureau (Art. 9).

Specifically, the activities that the working groups perform for the given State are carried out in the framework of expert visits, when the members of the expert group go to a place in the State for the purpose of gathering the information necessary for the implementation of legal aid in situ (Art. 10 of the Procedural Rules). On-site interaction is organised with the authorities of the State, and all the actions of the working group are conducted with the permission of the latter. The final documents of the working group in respect of one or another State are based on the results of the activities accomplished during the visit. The established reports should be discussed in the Secretariat of the Commission before becoming official (par. 5 and 6, Art. 10).

${ }^{12}$ Action Plan adopted at the Third Summit of Heads of State and Government of the Council of Europe (Warsaw, 16-17 May 2005).

${ }^{13}$ So, for example, an act relating to the methodology of the analytical work of the Commission - guiding rules for statistics related to the judiciary - was passed (CEPEJ, Guidelines on judicial statistics, CEPEJ(2008)11, adopted by the CEPEJ at $12^{\text {th }}$ plenary meeting (Strasbourg, 10-11 December 2008)).

${ }^{14}$ This opinion is shared, for example, by J. Petaux, L'Europe de la démocratie et des droits de l'homme: l'action du Conseil de l'Europe, Council of Europe Publishing, 2009, p. 126. 
The Commission performs the analysis of statistical data and legislative acts on justice systems of the Member States not only on its own initiative - that during its shortterm activities resulted in the acceptance of reports on the condition of the justice system of the concerned States but it can also provide its assistance to a given country if the latter makes a request in this respect (Art. 4 of the already cited resolution).

The Commission also interacts directly with the authorities of the Council of Europe, and in particular encourages them, if necessary, to develop and adopt a particular legal normative act, contributing to the development of the judiciary of the Member States. Thus, the work of the CEPEJ is not limited to the collection of information relating to the judiciary of the Member States, its analysis, and the provision of assistance to Member States (in particular legal), but is characterised by a concentrated work with the authorities of the Council of Europe.

In accordance with the above-quoted Resolution Res(2002)12 of the Committee of Ministers on the establishment of the CEPEJ as of 18 September 2002, the Commission's activities are specifically aimed at the implementation within the domestic legal order of the Member States of the European Convention obligations relating to the functioning of the judiciary, namely: Art. 5, 6, 13 and 14 of the European Convention, as well as articles of the protocols relating to the access to justice; the efficiency of judicial procedures; the enforcement of judgments; the status and role of judges, prosecutors, lawyers and other members of the judiciary; as well as the management and implementation within courts and their operating of modern communication technologies. In practice, the main activity of the CEPEJ was the publication of the Commission's reports on evaluation of the Member States judicial systems. Today, they go out on a regular basis ${ }^{15}$, aggregate a huge amount of statistical material, possess the analytical value and are quite voluminous, suggesting that their authority will only increase. These reports relate to all Member States of the Council of Europe, and are devised using data collected by the national representatives (correspondents) in the place (in the Member States). They enable the creation of a full picture of the judiciary of the Member States on the basis of uniform criteria, and present disadvantages/advantages of each of them on the basis of comparative analysis.

The reports are to be submitted to the Committee of Ministers of the Council of Europe. Moreover, Procedural Rules require from the President of the CEPEJ the orally submission of the reports before the Committee of Ministers.

${ }^{15}$ See, for example, the report for 2012: CEPEJ, European Judicial Systems: Edition 2012, Council of Europe Publishing, 2014, 422, p. URL: http://www.coe.int/T/dghl/co-operation/cepej/ evaluation/2012/Report_eng.pdf.
Another area of co-operation between the Council of Europe and the Member States are reports of the Commission prepared at the request of one or more countries. For example, the Commission analysed the policies and procedures for the selection of judges in the Republic of Azerbaijan, questions on territorial jurisdiction in the Netherlands, dematerialization and the use of ICT in Portugal, mediation in Switzerland ${ }^{16}$. Moreover, several reports concerning in particular the most painful problem of the Russian justice system, namely the execution of court decisions, as well as the report related to practical ways of combating delays in the justice system, excessive workloads of judges and case backlogs in Malta had been already implemented ${ }^{17}$. Thus, the Commission has been repeatedly called upon to carry out an analysis of national judiciary for compliance with the regulatory arch of the Council of Europe.

We can't not pay attention to another area of activity of the Commission, which is to issue the so-called "Lignesdirectrices" - or "Guidelines". We are talking about the advisory and framework documents that are designed to provide guidance to States to implement relevant reforms of their judiciary. Thus, for example, one of the guidelines of the Commission encompasses advices on the territorial location of courts and on the organization and the accessibility of court premises of the Member States, aimed at ensuring the availability of justice and the access to courts and at improving the quality of these services ${ }^{18}$. Likewise, the SATURN guidelines for judicial time management are aimed at monitoring the judicial timeframes ${ }^{19}$ and preventing the violations of the right to a fair trial within a reasonable

${ }^{16}$ CEPEJ Report on assessment of policy and procedures for the selection of judges in Azerbaijan, Strasbourg, 10 January 2012, CEPEJ-COOP(2011)1; CEPEJ Report on territorial jurisdiction in Netherlands, 05 December 2003; CEPEJ(2003)18(D3); CEPEJ Report on dematerialization and the use of ICT in Portugal, 11 June 2009, CEPEJ-COOP (2009)4; CEPEJ Report on mediation in Switzerland, CEPEJ(2003)25(D2)E, 5 December 2003.

${ }^{17}$ CEPEJ Report on examination of problems related to the execution of decisions by national civil courts against the state and its entities in the Russian Federation, Strasbourg, 9 December 2005, CEPEJ(2005)8; CEPEJ Report on nonenforcement of court decisions against the state and its entities in the Russian Federation: remaining problems and solutions required, Strasbourg, 31 October 2006, CEPEJ (2006)1; CEPEJ Report on practical ways of combating delays in the justice system, excessive workloads of judges and case backlogs in Malta, 8 April 2004, CEPEJ(2005)7E.

${ }^{18}$ CEPEJ Guidelines on the creation of judicial maps to support access to justice within a quality judicial system, 6 December 2013, CEPEJ(2013)7Rev1; CEPEJ Guidelines on the organization and accessibility of court premises, 12 December 2014, CEPEJ(2014)5.

${ }^{19}$ CEPEJ SATURN Guidelines for judicial time management, 12 December 2014, CEPEJ(2014)16. 
time enshrined in Article 6 of the European Convention on Human Rights.

One of the other significant areas of the CEPEJ work is the drafting of studies on different fields of justice. During the recent years the CEPEJ working groups drafted more than twenty studies, for example, the Working Group on the evaluation of judicial systems (CEPEJ-GT-EVAL) Study No. 19 on judicial systems of the European Union countries, Study No. 21 on judicial systems of the Eastern Europe countries ${ }^{20}$; the Centre for judicial time management (SATURN Centre) - Study No. 3 on length of court proceedings in the Member States of the Council of Europe based on the case-law of the European Court of Human Rights ${ }^{21}$, Study No. 17 on Council of Europe Member States Appeal and Supreme courts' lengths of proceedings 22 ; the Working Group on quality of justice (CEPEJ-GT-QUAL) - Study No. 15 on conducting satisfaction surveys of court users in Council of Europe Member States, Study No. 16 on the situation of the contractualisation and judicial process in Europe ${ }^{23}$, etc.

\footnotetext{
${ }^{20}$ Study No. 19 on judicial systems of the European Union countries, drafted by Mr. Jean-Paul Jean (former Advocate General at the Court of Cassation, Associate Professor at the University of Poitiers, France), and Ms. Hélène Jorry (Expert on European Union law, Associate expert in the CEPEJ), 2013; Study No. 21 on judicial systems of the Eastern Europe countries, drafted by Mr. Jean-Paul Jean (Court Section President of the Court of Cassation, Associate Professor at the University of Poitiers, France), and Mr. Ramin Gurbanov (Scientific expert of the Institute of Philosophy and Law/Azerbaijan National Academy of Sciences, Azerbaijan), 2015.

${ }^{21}$ Study No. 3 on length of court proceedings in the Member States of the Council of Europe based on the case-law of the European Court of Human Rights, drafted by Ms. Françoise Calvez (Judge), France, and up-dated by Mr. Nicolas Régis (Judge), France, 2011.

${ }^{22}$ Study No. 17 on Council of Europe Member States Appeal and Supreme Courts' lengths of proceedings, drafted by Mr. Marco Velicogna (IRSIG-CNR, CEPEJ expert), 2013.

${ }^{23}$ Study No. 15 on conducting satisfaction surveys of court users in Council of Europe Member States, drafted by Mr. JeanPaul Jean (former Advocate Generalat the Court of Appeal of Paris, Associate professor at the University of Poitiers, France), and Ms. Hélène Jorry (Teaching and research expert of the University of Versailles-Saint-Quentin-en-Yvelines, France), 2010; Study No. 16 on the situation of the contractualisation and judicial process in Europe, drafted by Mr. Julien Lhuillier (Institute of Criminology and Criminal Law, University of Lausanne, France), 2010.
}

According to the already quoted Resolution $\operatorname{Res}(2002) 12$ of the Committee of Ministers on the establishment of the Commission, the activity of the latter is focused on the organisation of co-operation between Member States (see Preamble). However, in our opinion, its activity deals, to a greater extent, with indirect co-operation within not only the Council of Europe as a whole, but in particular between the ECHR and the judicial authorities of the Member States. Indeed, if we take into account that the analysis and evaluation of the functioning of the judiciary of the Member States are based on the principles established by the European Convention which are dynamically construed by the ECHR, it becomes obvious that the ultimate criterion of the justice system quality of one or another State lies in the interpretations of the Convention given by this supranational judicial authority. In other words, the advices on improvement of judiciary, which the Commission has to formulate in the framework of its activities, are based on the provisions of the European Convention and the clarification of their content within the ECHR case-law, bearing in mind that all the Commission's activities are aimed at improving the judiciary of the Member States. This assertion is confirmed by the first President of the CEPEJ, Mr. Eberhard Desch, who in particular argued that the establishment of this authority was intended to provide the assurance of compliance with European standards in the area of justice ${ }^{24}$.

Moreover, this conclusion stems directly from the Resolution on the establishment of the Commission. Thus, the preamble to the Resolution, considering the purpose of the Commission, provides for that, in particular, it should take into account the 'Requirements of the European Convention on Human Rights', and more specifically its Art. 5, 6, 13 and 14, as well as the relevant provisions of the protocols and the case-law of the European Court of Human Rights... ${ }^{25}$ Accordingly, it can be stated that the Commission activity is indirectly aimed at the implementation of the ECHR case-law within the judiciary of the Member States, which implies the existence of a certain level of co-operation between the supranational judicial authority and the national authorities (including courts).

${ }^{24}$ E. Desch, Foreword, in European Judiciary 2002, Council of Europe Publishing, p. 5.

${ }^{25}$ Resolution Res (2002) 12 on establishment of the European Commission for the Efficiency of Justice (CEPEJ), adopted by the Committee of Ministers on 18 September 2002 at their 808 meeting.

\section{REFERENCES}

E. Desch, Foreword in European Judiciary 2002, Council of Europe Publishing.

F. Benoît-Rohmer, H. Klebes, Le droit du Conseil de l’Europe: vers un espacejuridiqueeuropéen, Council of Europe Publishing, 2005.

Interview with R. Lamponi, $12^{\text {th }}$ September 2005, quoted by J. Petaux in L'Europe de la démocratie et des droits de l'homme: l'action du Conseil de l'Europe, Council of Europe Publishing, 2009.

J. Petaux, L'Europe de la démocratie et des droits de l'homme: l'action du Conseil de l'Europe, Council of Europe Publishing, 2009. 